\title{
The Impersonal Use of German 1st Person Singular Ich
}

\author{
Sarah Zobel
}

\begin{abstract}
This paper replies to Ackema and Neeleman's (2018) claim that 1st person singular pronouns are grammatically blocked from having impersonal uses. In connection with this claim, they argue that the impersonal use of German 1st person singular ich described in Zobel 2014 does not exist. I show that Ackema and Neeleman's alternative analysis of the German data analyzed in Zobel 2014 is flawed, and that new considerations inspired by their proposal further support the claim that German $i c h$ has an impersonal use. This result not only has ramifications for Ackema and Neeleman's account of the morphosyntax and semantics of (impersonally usable) personal pronouns, but for anyone researching the morphosyntax and semantics of pronominal expressions and how these interact.

Keywords: impersonal use, first person singular pronouns, German ich, weak free adjuncts, predicative als-phrases
\end{abstract}

\section{Issue: Impersonal Uses of 1st Person Singular Pronouns}

One way to make general statements about humans is by using pronominal expressions that roughly contribute the meaning 'people in general', see (1).

(1) a. One can't expect one's guests to pay for one's party.

b. You can't expect your guests to pay for your party.

Cross-linguistically, we find languages that employ pronominal forms for which this is their "primary use" (dedicated impersonal pronouns, e.g., English one in (1a)), as well as languages that coopt personal pronouns for this task (impersonally used personal 
pronouns, e.g., English 2nd singular you in (1b)). Both types of pronominal strategies are still not well-understood. For impersonally used personal pronouns, in particular, the following central cross-linguistic questions remain: (i) Which personal pronouns can be used impersonally in which language? (ii) Which combinations of person, number, and gender specifications are, in principle, compatible with an impersonal use?

In their recent monograph, Ackema and Neeleman $(2018: 9,107)$ formulate a number of generalizations addressing (ii). One of them states that it is impossible for 1 st person singular pronouns to have an impersonal use. This is supported by English $I$ in (2), which cannot be interpreted as a statement about people in general.

(2) I can't expect my guests to pay for my party. （only speaker-referential) Other languages that, like English, allow for an impersonal use of their 2nd person singular pronouns (see, e.g., Siewierska 2004:212 for a list) also mostly do not seem to allow for an impersonal use of their 1st person singular pronouns; at least for most of these languages, the existence of such an impersonal use has not been discussed so far.

One language for which the existence of an impersonal use of its 1 st person singular pronoun has been discussed is German. In Zobel 2010, 2014, 2016, I argue that 1st singular ich 'I' has an impersonal use, which is, however, not as unrestrictedly available as the impersonal use of 2nd singular $d u$ 'you'. For an occurrence of ich to be understood impersonally, ich has to be accompanied by supporting material (Zobel 2014:32, 200-201): this can be a non-epistemic modal expression (e.g., a non-epistemic modal or conditional) and/or a predicative als-phrase (Engl. 'as'-phrase). Both types of supporting material are present in the attested example in (3) (Zobel 2014:1). ${ }^{1}$ 
(3) Ich kann doch als $\underline{\text { Brautpaar }}$ nicht von meinen Gästen erwarten, dass sie mir I can PRT as bridal.couple not from my guests expect that they me quasi die Feier finanzieren.

more.or.less the party finance

'A bridal couple can't expect their guests to more or less pay for the party!'

Example (3) contains a possibility modal kann 'can' that receives a deontic interpretation, and an als-phrase als Brautpaar 'as a bridal couple' for which ich serves as its associated argument. In Zobel 2014, I argue that (3) is a general statement about bridal couples that arises as follows: ich is interpreted roughly like 'people in general' (i.e., just like English one and impersonally used you in (1)), but this contribution is restricted by the als-phrase to denote 'bridal couples in general' (Zobel 2014:285).

If German 1st singular ich does indeed have an impersonal use, it is a counterexample to Ackema and Neeleman's generalization. Ackema and Neeleman are aware of this data and my analysis, but they argue that 1st person singular pronouns in examples like (3) are not used impersonally. According to them, what I mistake for the semantic contribution of an impersonal use is an interpretive effect that arises as a result of the cooccurring als-phrase als Brautpaar 'as a bridal couple'.

The goal of this paper is to argue again in favor of my analysis in Zobel 2014 and to show that the evidence points towards German 1st singular ich having an impersonal use. I first discuss Ackema and Neeleman's argument against my analysis and highlight its empirical and theoretical flaws (section 2). Next, in section 3, I show that there is no evidence that German als-phrases are the source of the generality expressed by sentences 
like (3), or that they have the interpretive effect that Ackema and Neeleman claim them to have. Lastly, in section 4, I reaffirm my analysis in Zobel 2014 that German 1st singular $i c h$ has an impersonal use by showing that $i c h$ behaves semantically just like 2 nd singular $d u$ 'you', for which it is uncontroversial that it has a referential and an impersonal use.

Before starting out, let me briefly address the relevance of clarifying whether German ich has an impersonal use or not. Ackema and Neeleman's claim that 1st person singular pronouns are grammatically incompatible with an impersonal use has ramifications for the current morphosyntactic and semantic research on personal pronouns. One of the central lines of research combining the morphosyntax and semantics of personal pronouns investigates how the denotation of personal pronouns relates to their $\phi$-features, and how these denotations may be composed from these $\phi$-features if we assume that $\phi$-features contribute the building blocks of pronominal meaning (see, e.g., Ackema and Neeleman 2018; Kratzer 2009; Sudo 2012; and references therein). Impersonal uses of personal pronouns constitute important test cases for accounts that aim to address these questions_-in particular in connection with the treatment of person features. For instance, proposals discussing 2nd person singular pronouns, like English you, need to simultaneously account for the addressee-referential use and the impersonal (i.e., non-referential) use, which can result in a generic statement that does not apply to the addressee. ${ }^{2}$ That is, if the 2 nd person feature is hard-wired to contribute reference to the addressee, as in Kratzer 2009, what happens with this hard-wiring in the impersonal use?

Ackema and Neeleman (2018) are one of the first who aim to provide a featurebased account that captures all and only those referential and impersonal interpretations 
that are cross-linguistically possible. This is a difficult task, for which it is essential to start with as complete an overview of the cross-linguistic data as possible. So, their dismissal of the German data as an "apparent exception" (p. 109) to their generalization about 1st person singular pronouns has to be well-founded. This is not only important for their own account, given their claim that their feature system is "sufficient to generate an adequate typology of impersonal pronouns and their various interpretations" (p. 106). Inaccurately denying the existence of impersonally used 1st person singular pronouns also has ramifications for future investigations that might take their generalizations at face value.

As outlined above, I will argue that German ich does indeed have an impersonal use. Given Ackema and Neeleman's counterproposal, the argument mainly focuses on the interpretation of German als-phrases. Establishing the relevant semantic details may at times get tedious, but they are central to the main goal of this paper: to show that 1 st person singular pronouns are not grammatically blocked from being used impersonally.

\section{Ackema and Neeleman's (2018) Counterproposal}

This section provides a critical discussion of Ackema and Neeleman's (2018:109-112;

henceforth: A\&N) counterproposal to the claim I defended in Zobel 2014 that German 1st singular ich has an impersonal use in examples like (3). In brief, A\&N's counterproposal is that any "generic flavor" (p. 109) that is perceived for the German examples arises as a result of the cooccurring als-phrase. ${ }^{3}$

The central empirical flaw of A\&N's discussion is their decision to forgo examining German examples; their entire argument in favor of their counterproposal is based on their translation of (3) into Dutch, see (4). They justify this switch from German to Dutch by 
stating that "the kind of example that illustrates this [i.e., the putative impersonal use of German ich, SZ] is also attested in Dutch" (p. 109). However, with the risk of stating the obvious, patterns in the syntax and semantics of expressions of one language are not automatically valid for their counterparts in other languages_-even if these languages belong to the same language family, and the expressions in question are diachronically related. So, even if A\&N's proposal accurately captures their intuitions for Dutch, which I will not discuss in this paper, there is no guarantee that their analysis of these intuitions adequately extends to German, unless they show that their observations about Dutch also hold for German. Since they never address German, they thus do not show that German $i c h$ cannot be used impersonally; they only show that Dutch $i k$ plausibly cannot.

In the remainder of this section, I present A\&N's argument for why the als-phrase and not $i k$ contributes the intuitive generic flavor of (4), and I discuss their proposal for how this generic flavor arises. ${ }^{4}$ The applicability to German is addressed in Section 3.

A\&N's central argument for why the generic flavor of (4) is contributed by the cooccurring als-phrase is that it disappears when the als-phrase is omitted: with (5), the speaker can only talk about herself. ${ }^{5}$

(4) Ik kan toch $\underline{\text { als }} \underline{\text { bruidspaar }}$ niet verwachten dat de gasten het feest betalen.

I can PRT as bridal.couple not expect that the guests the party pay

'One cannot expect the guests to pay for the party when one gets married.' (p. 109) 
(5) Ik kan toch niet verwachten dat de gasten het feest betalen.

I can PRT not expect that the guests the party pay

'I cannot expect the guests to pay for the party.'

(unavailable: 'One cannot expect the guests to pay for the party.')

This omission test contrasts $i k$ with the weak 2 nd singular pronoun $j e$ 'you', which has an impersonal use. Impersonally used je can also associate with an als-phrase, as in (6a), but the generic interpretation persists when the als-phrase is omitted, compare (5) to (6b).

(6) a. Je kan toch als bruidspaar niet verwachten dat...

you.SG can PRT as bridal.couple not expect that

'One cannot expect that [...] when one gets married.'

b. Je kan toch niet verwachten dat...

you.SG can PRT not expect that

'One cannot expect that...' (generic)

'You cannot expect that...' (referential)

(p. 112)

Hence, for Dutch 1 st singular $i k$ but not for 2 nd singular je, the presence or absence of an als-phrase seems to determine whether the containing sentence has a generic flavor.

The core of A\&N's proposal for how the generic flavor with $i k$ arises is that the function of the als-phrase in sentences like (4) and (7) is to describe a "guise" (p. 110) of the referent of its associated argument (i.e., the subject). This guise may be one of the functions that the associated referent actually has, or it may be "imaginary" in the sense that "the associated referent need not actually have the attribute described" (p. 110). Thus, the als-phrase in (4) is taken to describe an imaginary guise of the speaker (since the 
speaker is not a bridal couple), while the als-phrase in (7) is taken to describe an actual guise of the referent of $z e$ 'she' (assuming that the referent of $z e$ is in fact a mayor).

(7) Ze kan als burgemeester toch niet verwachten dat de gasten het feest betalen. she can as mayor PRT not expect that the guests the party pay 'As a mayor, she cannot expect her guests to pay for the party.'

The generic flavor observed with these sentences arises because the als-phrase affects the main predication: the main clause predicate is applied to the subject referent only in the guise described by the als-phrase. As a result of this restriction, A\&N claim, examples with als-phrases imply general statements that link the als-predicate to the main clause predicate. Hence, (4) implies that bridal couples can't expect their guests to pay for the party, and (7) implies that mayors can't expect their guests to pay for the party.

The final ingredient of their proposal is that imaginary guises, but not actual guises, are restricted with respect to their associated arguments. In declarative clauses, als-phrases contributing imaginary guises can only associate with 1st person singular pronouns, as in (4), while in interrogative clauses, they can only associate with strong 2nd person singular arguments, see (9a). This restriction lies behind the difference in grammaticality between (7) (actual guise) and (8) (imaginary guise), and captures the difference in acceptability between (9a) (interrogative) and (9b) (declarative). ${ }^{6}$

(8) *Ze kan als bruidspaar toch niet verwachten dat... she can as bridal.couple PRT not expect that 
(9) a. Zou jij als bruidspaar verwachten dat de gasten het feest betalen? would you.SG as bridal.couple expect that the guests the party pay 'Would one expect the guests to pay for the party when one gets married?' b. *Jij zou toch $\underline{\text { als }} \underline{\text { bruidspaar }}$ niet verwachten dat... you.SG would PRT as bridal.couple not expect that

According to $\mathrm{A} \& \mathrm{~N}$, this restriction is in place because als-phrases contributing imaginary guises require "access to the referent's mind" (p. 110), which, they argue, is only ensured in declarative clauses with 1st person singular pronouns and interrogative clauses with 2nd person singular pronouns.

The main theoretical flaw with A\&N's counterproposal is that its parts remain unclear; the authors neither define them, nor do they provide relevant references to understand them.

A\&N's claim that the function of Dutch als-phrases is to describe actual or imaginary guises seems to be motivated entirely by their intuitions about example (7), which, according to them, makes this function "apparent" (p. 110). I am not aware of any in-depth investigations of the syntax and semantics of Dutch als-phrases, although they have been at least addressed by de Swart et al. (2007). There are, however, syntactic and semantic investigations of English as-phrases and German als-phrases (e.g., Asher 2006, 2011; Flaate 2007; Jäger 2003; Szabo 2003; Zifonun 1998; Zobel 2017, 2018, 2019), as well as investigations of syntactically and semantically comparable expressions (i.e., free adjuncts, which include all types of secondary predicates, see, e.g., Fabricius-Hansen and Haug 2012; Stump 1985). A\&N do not connect their claim to any of these works. 
A\&N also do not clarify which notion of guise they have in mind. In the literature, one notion is introduced by Heim (1998:214), for whom a guise is a contextually salient way in which an individual (e.g., the referent of a personal pronoun) is presented to the interlocutors. Another notion of guise is introduced by Safir, who uses it to talk about cases where "one person's perspective is put into the shoes of another [individual]" (Safir 2004:115). Neither notion of guise fully captures what A\&N use the term "guise" for. Heim's notion of guise might work for cases like (7) (i.e., "she" is identified via her function as a mayor), but it is implausible that the speaker uses a Heimian guise to self-identify in (4). In contrast, Safir's notion of guise might work for A\&N's imaginary guises (4) (i.e., the speaker takes on the perspective of some bridal couple), but the referent in (7) is not said to adopt someone else's perspective: as A\&N state, "she" in (7) has the function of being a mayor, so "she" does not take on someone else's perspective when she acts as a mayor. Hence, it is unclear what A\&N mean by "guise". 7

Lastly, the status of the translation A\&N provide for (4) remains unclear throughout their discussion. According to them, the generic flavor is the result of an "implication" (p. 110). This crucially differs from my own proposal in Zobel 2014: I argue that the truthconditional content of sentences like (3) is that of a generic sentence. So, if the translation in (4) is the result of an implication, what is the non-generic truth-conditional content?

In sum, Ackema and Neeleman (2018:109-112) argue that for Dutch $i k$, any perceived generic flavor in examples like (4) is tied to the presence of a predicative als-phrase that describes an imaginary guise of the associated referent (i.e., the speaker). The empirical and theoretical bases for this claim remain unclear. 


\section{Checking Ackema and Neeleman's Claims for German}

In this section, I show that the two central points of A\&N's argumentation for Dutch do not hold for German. First, I show that sentences containing ich but no als-phrase can have a generic interpretation, and second, I show that there is no evidence that German predicative als-phrases have the special use that A\&N describe for Dutch als-phrases. ${ }^{8}$

\subsection{Als-Phrases Are Not Necessary in German}

As A\&N (2018:111) point out, it would be a problem for their counterproposal if the generic interpretation that arises with German ich did not need a cooccurring als-phrase. Here, they quote my statement that in German, sentences with ich do not require the presence of an als-phrase in order to receive a generic interpretation (Zobel 2014:32-33). They reply to this that "the Dutch equivalent of the example she cites does not allow the apparent generic reading at all" (p. 111-112). As I argued in the previous section, this may very well be, but the semantic behavior of Dutch $i k$ does not automatically determine the interpretive possibilities for German ich. Hence, the relevant German data supporting my claim deserve at least another look.

In order to show that als-phrases are not necessary for the impersonal use of German ich, I give the constructed example in (10), which has a generic interpretation in the given context even though it does not contain an als-phrase.

(10) [Context: A and B see someone knock over bikes for fun.]

A: Sowas kann ich doch nicht machen! something-like-this can I PRT not do

'One shouldn't do something like that!'

(Zobel 2014:36) 
In (10), A does not say that A cannot knock over bikes for fun. The utterance is used to communicate that the actions witnessed by $\mathrm{A}$ and $\mathrm{B}$ are reprehensible because they violate a general (moral) rule. The same statement could be formulated, for instance, with a dedicated impersonal pronoun like English one, as in the given translation.

Since example (10) is constructed, one might argue that examples like these do not occur "in the wild", and that impersonally used ich de facto always cooccurs with an als-phrase. That this is also not the case is shown by the attested example in (11).

(11) [Context: Soccer player A comments on the lack of effort put into the match by the opposing team, who are close to being relegated.] ${ }^{9}$

A: In so einer Situation muss ich doch 90 Minuten lang Gas geben. in such a situation must I PRT 90 minutes long gas give 'In such a situation, one has to work hard for 90 minutes.'

In the given context, it is clear that the speaker in (11) does not report a necessity for himself: A is not part of the team that faces relegation, and the issue is not what A's obligations are in a comparable situation. With his statement, A reports his beliefs about how soccer players in general should behave when their team is close to being relegated. And just as for (10), the same general statement about individuals in such a situation can be formulated with a dedicated impersonal pronoun, as in the translation.

The astute reader may have observed that (10) and (11) both contain expressions that contain so 'such' and express comparative meaning: sowas 'something like that' and in so einer Situation 'in such a situation'. Defenders of A\&N's counterproposal could argue that these expressions are ambiguous and have the same semantic effect that A\&N 
ascribe to als-phrases (i.e., they are the sources of the perceived generic flavor). And just as for als-phrases, they would have to assume that these expressions have their special, generic-flavor-inducing meaning only in connection with first singular ich because no generic interpretation arises with 3rd singular er 'he', see (12).

(12) [Context: A and B see a woman knock over bikes for fun.]
A: \#Sowas
kann er doch nicht machen!

something-like-this can he PRT not do

'He shouldn't do something like that!')

(unavailable: 'One shouldn't do something like that!')

The only possible interpretation for A's utterance in (12) is one that makes a statement about a specific male individual, hence A cannot use it to talk about the woman knocking over bikes, and the entire utterance is pragmatically odd. Similarly, if ich in (11) were substituted with $e r$ 'he', the resulting utterance would be odd in the given context because there is no single male individual that A could be taken to talk about. In order to talk about the players of the other team, A would have to use 3rd plural sie or die 'they'. If impersonally used $i c h$ had to cooccur with either an als-phrase or an adjunct with comparative meaning, an extended version of A\&N's counterproposal might still be a viable option. However, we do find attested examples of impersonally used ich that do not contain any adverbial expressions, see (13). ${ }^{10}$

(13) [Context: In a forum for cars built by Audi, A posts a question about tuning the electronics of his Audi to lower gas consumption. He replies to an answer. $]^{11}$ 
A: Deswegen frage ich hier nach Erfahrungen von Verbrauchern, denn als Firma therefore ask I here after experiences of consumers because as company kann ich natürlich viel erzählen. Ich will ja schliesslichwas verkaufen. can I naturally much tell I want.to PRT PRT something sell 'That is why I am asking for experiences of consumers because as a company, one can claim a lot. One wants to sell something, after all.'

In (13), A's second sentence expresses a generality about companies (i.e., they want to sell something). So, even though the second sentence contains $i c h$ but no adverbial expressions (ja and schließlich are discourse particles, see footnote 1), the sentence can express a generic statement. Indeed, ich in the second sentence seems to be anaphoric to the occurrence of ich that associates with the als-phrase als Firma 'as a company', just like the second occurrence of one in the translation is anaphoric to the first occurrence.

So, instead of assuming multiple ambiguities for non-obligatorily cooccurring material just to avoid the assumption of an impersonal use for $i c h$, as well as trying to explain away examples like (13), it would be more parsimonious from a theoretical point of view to assume that German 1st singular ich has a special use that comes with a generic interpretation, an impersonal use.

\subsection{There Is No Evidence for a Special Use of German Als-Phrases}

Let us now take a closer look at whether there is evidence that predicative als-phrases in German have a special use that is restricted to referentially used 1st singular associated arguments in declarative clauses and 2nd singular associated arguments in interrogative clauses. In order to establish the availability of this special use in the absence of 1 st 
singular ich, I analyze the translations of A\&N's Dutch examples (9b) and (9a), which contain the strong 2 nd singular pronoun $j i j$.

I translate (9a) and (9b) as (14) and (15), respectively. The main challenge in translating (9a) and (9b) lies in the fact that German does not have a strong 2nd singular pronoun that directly corresponds to Dutch $j i j$. In order to get as close as possible to a 2nd singular pronoun that is necessarily referential, I use the regular German 2nd singular pronoun $d u$ but assume that it is stressed (indicated by upper case). Stress has been argued to promote or even force a referential interpretation for impersonally usable personal pronouns (see Gruber 2013; Zobel 2014). So, $D U$ is strictly addressee-referential.

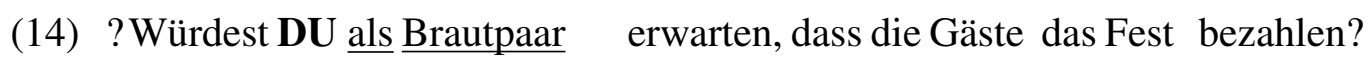
would you as bridal.couple expect that the guests the party pay 'Would $\mathrm{YOU}_{s g}$ as a bridal couple expect that the guests pay for the party?' (15) ?DU würdest doch als $\underline{\text { Brautpaar }}$ nicht erwarten, dass die Gäste bezahlen. you would PRT as bridal.couple not expect that the guests pay 'As a bridal couple, YOU $_{s g}$ wouldn't expect that the guests pay.'

A first contrast between the Dutch examples and the German translations concerns their grammaticality: A\&N state that (9a) is grammatical, while (9b) is ungrammatical. This difference in grammaticality serves as evidence for their claim that the genericityinducing, restricted use of predicative als-phrases is sensitive to whether the "[associated] referent's mind" (A\&N 2018:110) is accessible: for 2nd singular $j i j$, this is only the case in an interrogative clause (i.e., in (9a)). In contrast, the German translations in (14) and (15) are both grammatical; they are just equally semantically odd because the property of 
being a bridal couple is ascribed to a single individual (i.e., the addressee).

Another difference to the Dutch example in (9a) arises with respect to A\&N's claim that the restricted use of Dutch als-phrases implies a general statement. That is, (9a) is said to imply a general question about bridal couples. However, in their most natural interpretation neither (14) nor (15) imply a generalization about bridal couples: both sentences are about non-actual situations in which the addressee is (part of) a bridal couple and are best paraphrased with counterfactual conditionals, see (16).

$$
\begin{aligned}
& (14) \approx \text { 'If } \mathrm{YOU}_{s g} \text { were a bridal couple, would you expect that ...?' } \\
& (15) \approx \text { 'If } \mathrm{YOU}_{s g} \text { were a bridal couple, you wouldn't expect that...' }
\end{aligned}
$$

Like these counterfactual conditionals, (14) and (15) can be uttered regardless of the generalizations pertaining to the expectations of bridal couples in general. That is, it is not inconsistent to utter either sentence after establishing that bridal couples in general expect their guests to pay for their party. For A\&N's example (9a), this should be impossible.

Taken together, these two contrasts between the German data in (14) and (15) and what A\&N say about (9a) and (9b) support the conclusion that the German als-phrases do not have the special use that A\&N describe for Dutch. In fact, the two als-phrases in (14) and (15) show exactly the behavior that we would expect if they were used as weak free adjuncts (see Fabricius-Hansen and Haug 2012; Stump 1985; Zobel 2018, 2019). Whenever German als-phrases (and English as-phrases) are used as weak free adjuncts, they intuitively contribute an adverbial-clause-like interpretation that varies between a causal-clause-like, conditional-clause-like, or temporal-clause-like interpretation. These interpretations are similar to that of since-clauses, hypothetical if/when-clauses, and 
temporal when-clauses, respectively (e.g., Stump 1985; Zobel 2018).

While the causal-clause-like interpretation is available for any als-phrase in this use, the availability of the other two interpretations depends on the presence of cooccurring temporal and modal operators. This range of readings is illustrated in (17) and (18).

(17) $\underline{\text { Als }}$ Katzenfreund besitzt Peter zwei Katzen.

as cat.lover owns Peter two cats

'As a cat lover, Peter owns two cats.'

(Zobel 2019:499)

Since (17) does not contain any temporal or modal operators, the als-phrase can only be interpreted like a since-clause: 'Since Peter is a cat lover, he has two cats'. In contrast, the sentences in (18) contain temporal and modal operators that potentially interact with the cooccurring als-phrases, so these examples are ambiguous.

(18) a. Als Kind war Hannah schüchtern.

as child was Hannah shy

'As a child, Hannah was shy.'

(past tense)

( $\approx$ 'When Hannah was a child, she was shy.')

$(\approx$ 'Since Hannah is a child, she was shy.')

b. Als Kind würde Hannah nichts zahlen.

as child would Hannah nothing pay

'As a child, Hannah would not pay anything.'

(would)

( $\approx$ 'If Hannah were a child, she would not pay anything.')

( $\approx$ 'Since Hannah is a child, she would not pay anything.')

The sentence in (18a) contains a past temporal operator. When the als-phrase als Kind 'as 
a child' interacts with this operator, the als-phrase is intuitively interpreted like a temporal when-clause; when the als-phrase and the operator are interpreted independently from each other, the result is a since-clause-like interpretation. Similarly, the sentence in (18b) contains an irrealis modal. When the als-phrase interacts with the irrealis modal, it is interpreted like a hypothetical if-clause; when the als-phrase and the irrealis modal are interpreted independently, the result is a since-clause-like interpretation.

The als-phrases in (14) and (15) show the same range of interpretations that is possible for the als-phrase in (18b). The paraphrases in (16) capture the conditionalclause-like interpretations that arise from an interaction of the als-phrase with the modal operator würde 'would'. But just like the als-phrase in (18b), the als-phrases in (14) and (15) can also get a since-clause-like interpretation, see (19).

$(14) \approx$ 'Since $\mathrm{YOU}_{s g}$ are a bridal couple, would you expect that ...?' $(15) \approx$ 'Since YOU $_{s g}$ are a bridal couple, you wouldn't expect that...'

The conditional-clause-like interpretation paraphrased in (16) is preferred over the causalclause-like interpretation paraphrased in (19) because in the causal-clause-like interpretation, the predicate described by the als-complement (i.e., being a bridal couple) is ascribed to the associated referent (i.e., the addressee) in the actual world. In other words, for the paraphrases in (19) to be true, the singular addressee has to be a bridal couple, which is, strictly speaking, always false. This is not the case when the als-phrases get a conditional-clause-like interpretation in connection with würde 'would'. In that case, the predicate denoted by the als-complement (i.e., being a bridal couple) is counterfactually ascribed to the associated referent (i.e., the addressee). That is, the 
paraphrases in (16) require the addressee to have counterparts that are (parts of) bridal couples, which is possible.

In connection with any general statements that might be implied by either (14) and (15), we find that an als-phrase with a causal-clause-like interpretation implies a generalization that connects the als-complement and the main clause predicate only when the als-phrase occurs in a declarative sentence / an assertion. We have seen above that als-phrases with a conditional-clause-like interpretation do not imply general statements. For the declarative sentence in (15), we observe that the causal-clause-like interpretation implies that bridal couples in general don't expect that their guests pay for the party. The causal-clause-like interpretation of the als-phrase in the interrogative sentence in (14), however, has a different effect. Like its paraphrase in (19), it provides an explanation for why the speaker poses the question to the addressee, which is not (necessarily) based on what is true for bridal couples in general and, thus, does not imply this generality.

In sum, section 3 has added to the evidence showing that in German, als-phrases are not necessary for a generic interpretation of 1 st singular $i c h$. In addition, we have seen that there is no evidence for a restricted use of German als-phrases in connection with referentially used 2 nd person singular pronouns. In fact, the German als-phrases that associate with referential $d u$ in the translations of Ackema and Neeleman's Dutch examples behave like regular weak free adjuncts, which show a very different behavior from the restricted use that Ackema and Neeleman describe for Dutch als-phrases. 


\section{German Ich Has an Impersonal Use}

I now return to my original German example (3) and provide one further argument in favor of an impersonal use for 1st singular ich 'I'. If $i c h$ in (3) were used referentially (as suggested by Ackema and Neeleman (2018:109-112)), then promoting a referential interpretation of $i c h$ by stressing the pronoun should not have an effect on the acceptability and interpretation of the example.

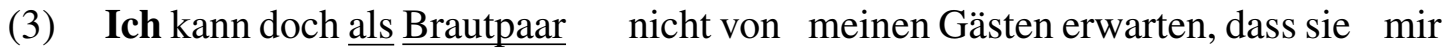
I can PRT as bridal.couple not from my guests expect that they me quasi die Feier finanzieren.

more.or.less the party finance

'A bridal couple can't expect their guests to more or less pay for the party!'

This is, however, not the case: the intuitive interpretations of (3) and (20) differ fundamentally. I start investigating this unexpected contrast by taking a closer look at (20). (20) ?? ICH kann doch $\underline{\text { als }}$ Brautpaar nicht erwarten, dass die Gäste das Fest bezahlen.

I can PRT as bridal.couple not expect that the guests the party pay

'As a bridal couple, I can't expect that the guests pay for the party.'

( $\approx$ Since I am a bridal couple, I can't expect that the guests pay for the party.) Just as in (15) (repeated below), the als-phrase in (20) is a weak free adjunct that cooccurs with a modal verb. For (15), the presence of the modal würde 'would' was argued to make the sentence ambiguous between a preferred interpretation where the als-phrase is interpreted like a hypothetical if-clause $(\approx$ 'If YOU were a bridal couple, you wouldn't expect that...') and a less prominent interpretation where the als-phrase is interpreted like 
a since-clause ( $\approx$ 'Since YOU are a bridal couple, you wouldn't expect that...').

(15) ?DU würdest doch $\underline{\text { als }} \underline{\text { Brautpaar }}$ nicht erwarten, dass...

you.SG would PRT as bridal.couple not expect that

'As a bridal couple, YOU $_{s g}$ wouldn't expect that...'

As indicated in (20), the als-phrase in (20) can only get a since-clause-like interpretation. Why does (20) not have a conditional-clause-like interpretation, as well? This is due to the type of modal that is used. Weak adjunct als-phrases are only found to interact with irrealis modals, like würde 'would'. They cannot interact with epistemic or root modals (Zobel 2018). This is shown for deontic kann 'can' in (21).

(21) [Context: Lisa needs legal advice. The trade union offers legal advice to members, but Paul doesn't know whether Lisa is a member.] (intended: deontic kann)

P: \#Als Gewerkschaftsmitglied kann Lisa um Rechtsberatung ansuchen.

as union.member can Lisa about legal.advice apply

'As a member of the union, Lisa can apply for legal advice.'

( $\approx$ 'Since Lisa is a member of the union, she can apply for legal advice.')

(unavailable: 'If Lisa is a member of the union, she can apply for legal advice.')

If the als-phrase in (21) were able to interact with deontic kann 'can', we would expect the sentence to have an interpretation that is comparable to a hypothetical indicative conditional $(\approx$ 'If Lisa is a member of the trade union, ...'). With such an interpretation, (21) would be acceptable in the given context: Paul does not know whether Lisa is a member of the union, but if she is, she can apply for legal advice. This interpretation is, however, unavailable for (21). The als-phrase can only have a causal-clause-like 
contribution $(\approx$ 'Since Lisa is a member of the trade union, she can apply for legal advice'), which results in Paul's utterance being in conflict with the context.

Example (20), like (21), contains deontic kann 'can'. Hence no conditional-clauselike interpretation is available for the als-phrase; only the causal-clause-like interpretation is possible. As shown in section 3.2, als-phrases with a causal-clause-like interpretation that occur in assertions imply a generic statement that connects the als-complement and the main clause predicate. Hence, in addition to the truth-conditional denotation given, (20) implies that bridal couples can't expect their guests to pay for the party. ${ }^{12}$

So, both (3) and (20) intuitively convey that bridal couples can't expect their guests to pay for their wedding party. However, there is an important difference: The general statement about bridal couples that is understood for (20) is implied as a result of the causal-clause-like interpretation of the als-phrase and is understood in addition to the semantically odd truth-conditional denotation (i.e., for (20) to be true, the speaker has to be a bridal couple). Notably, no such oddness arises with (3). So, if the semantic oddness of (20) is the result of a semantic mismatch between the predicate contributed by the als-phrase and the associated referent (i.e., the speaker), the lack of semantic oddness for (3) suggests that its interpretation does not involve ascribing the property of being a bridal couple to the actual speaker-that is, (3) and (20) are not semantically equivalent.

In order to see that ich in (3) behaves exactly like an impersonally used personal pronoun, let us compare its behavior in (3) and (20) to that of a pronoun for which it is uncontroversial that it has an impersonal use: 2 nd singular $d u$ 'you'. When ich is exchanged for $d u$ in (3) and (20), we observe the same contrast in acceptability and 
interpretation—both for the German examples and their English translations, see (22).

(22) a. Du kannst doch $\underline{\text { als }} \underline{\text { Brautpaar }}$ nicht erwarten, dass $\ldots$

you can PRT as bridal.couple not expect that...

'As a bridal couple, you can't expect that...'

b. ??DU kannst doch $\underline{\text { als }} \underline{\text { Brautpaar }}$ nicht erwarten, dass ...

you can PRT as bridal.couple not expect that...

'As a bridal couple, YOU can't expect that...'

Just like (3), (22a) intuitively denotes a general statement about bridal couples, and the sentence is not semantically odd even though $d u$ associates with als Brautpaar 'as a bridal couple'. And just like (20), (22b) involves an als-phrase with a causal-clause-like interpretation $(\approx$ 'Since YOU are a bridal couple...'), which implies a general statement about bridal couples, but also makes the sentence semantically odd since being a bridal couple is directly ascribed to the singular addressee.

For 2nd singular $d u$ (and impersonally usable 2nd person singular pronouns of other languages), the contrast in (22) is due to the distinction between the referential use and the impersonal use of $d u$. The interpretation of (22b), which contains stressed, addresseereferential $d u$, arises in exactly the same way as described for (20). But, how does the generic interpretation of (22a) arise?

For impersonally interpreted $d u$, the interpretation of its containing sentence involves the generic operator GEN, which underlies the intuitive interpretation of impersonal pronouns as "people in general" (see e.g., Kitagawa and Lehrer 1990; Malamud 2006, 2012, 2013; Siewierska 2004; Zobel 2014). While there is no consensus 
regarding the exact semantic contribution of GEN, it is clear that GEN has intensional semantics and is, hence, a modal operator (see e.g., Krifka et al. 1995; Mari et al. 2013). As shown above, als-phrases do not interact with all modal operators, so before we can continue with (22a), we need to establish first that als-phrases can interact with GEN.

The sentence in (23) is a generic sentence with an indefinite singular subject ein Hund 'a dog' that associates with a weak free adjunct als-phrase als Welpe 'as a puppy'.

(23) Als Welpe kann ein Hund seine Energie nicht kontrollieren.

as puppy can a dog his energy not control

'As a puppy, a dog can't control its energy.'13

Example (23) is ambiguous. One interpretation arises from the als-phrase getting a causal-clause-like interpretation ( $\approx$ 'Since dogs are puppies...'); in this interpretation, (23) is true if dogs, in general, are puppies and is, therefore, false. The reasonable and more natural second interpretation of (23) is understood when the als-phrase is interpreted like a hypothetical when-clause $(\approx$ 'When dogs are puppies...'). This interpretation arises as a result of the als-phrase interacting with GEN, the only modal operator in (23).

Having established that als-phrases can interact with GEN, we can assume that the als-phrase als Brautpaar 'as a bridal couple' in (22a) can get a hypothetical conditionalclause-like interpretation. As a result, (22a) can be interpreted like a generic conditional: (24) 'When people are bridal couples, they can't expect their guests to pay for the party.' This is the interpretation for impersonally used personal pronouns I propose in Zobel 2014 and the basis for the following non-conditional paraphrase of (22a): 'Bridal couples can't expect their guests to pay for the party.' No semantic oddness is expected to arise for (22a) 
in this interpretation because the property 'being a bridal couple' is not ascribed to a single individual but to couples in the set of "people in general".

To sum up, we have seen that the contrast observed for $i c h$ in (3) and (20) mirrors the contrast between (22a) and (22b), which can be attributed to the distinction between the impersonal use and the referential use of $d u$. So, given this parallel between 1 st singular ich and 2nd singular $d u$, we have one further reason to assume that the general statement about bridal couples conveyed by (3) is based on an impersonal use of 1st singular ich.

\section{Conclusion}

In this paper, I argued against the claim made by Ackema and Neeleman (2018) that German 1st singular ich 'I' does not and cannot have an impersonal use, and in turn provided new arguments in favor of the claim I put forth in Zobel 2014 that $i c h$ has an impersonal use that parallels the impersonal use of German 2nd singular $d u$ 'you'.

Returning to the bigger picture, this result means that 1st person singular pronouns are not grammatically blocked from having impersonal uses (pace Ackema and Neeleman 2018), and just as for 2nd person singular pronouns, any account that connects the morphosyntax and the semantics of 1 st person singular pronouns needs to accommodate the possibility that these pronouns may be used impersonally in one language or another.

\section{References}

Ackema, Peter, and Ad Neeleman. 2018. Features of Person: From the Inventory of Persons to Their Morphological Realization. Cambridge, MA: MIT Press.

Asher, Nicholas. 2006. Things and their aspects. Philosophical Issues 16:1-23. https://doi.org/10.1111/j.1533-6077.2006.00100.x. 
Asher, Nicholas. 2011. Lexical Meaning in Context: A Web of Words. Cambridge University Press.

Fabricius-Hansen, Cathrine, and Dag Haug. 2012. Big events, small clauses. Berlin/Boston: De Gruyter.

Fine, Kit. 1982. Acts, events, and things. In Sprache und Ontologie. Proceedings of the Sixth Wittgenstein Symposion, ed. by Werner Leinfellner, Eric Kraemer, and Jeffrey Schank, 97-105. Wien: Hoelder-Pichler-Tempsky.

Flaate, Inghild. 2007. Die “als”-Prädikative im Deutschen. Eine syntaktisch-semantische Analyse. Tübingen: Stauffenburg.

Grosz, Patrick G. 2021. Discourse Particles. In The Wiley Blackwell Companion to Semantics (SemCom), ed. by Daniel Gutzmann, Lisa Matthewson, Cécile Meier, Hotze Rullmann, and Thomas Ede Zimmermann. Oxford: Wiley. https://doi.org/10.1002/9781118788516.sem047.

Gruber, Bettina. 2013. The Spatiotemporal Dimensions of Person: A Morphosyntactic Account of Indexical Pronouns. Doctoral Dissertation, Utrecht University.

Heim, Irene. 1998. Anaphora and Semantic Interpretation: A Reinterpretation of Reinhart's Approach. In The Interpretive Tract (MITWPL 25), ed. by Uli Sauerland and Orin Percus, 205-246. Cambridge, MA: MIT.

Jäger, Gerhard. 2003. Towards an explanation of copula effects. Linguistics and Philosophy 26:557-593. https://doi.org/10.1023/A:1025807726287. 
Kitagawa, Chisato, and Adrienne Lehrer. 1990. Impersonal uses of personal pronouns. Journal of Pragmatics 14:739-759.

https://doi.org/10.1016/0378-2166(90)90004-w.

Kratzer, Angelika. 2009. Making a Pronoun: Fake Indexicals as Windows into the Properties of Pronouns. Linguistic Inquiry 40:187-237. https://doi.org/10.1162/ling.2009.40.2.187.

Krifka, Manfred, Francis Jeffry Pelletier, Gregory N. Carlson, Alice ter Meulen, Gennaro Chierchia, and Godehard Link. 1995. Genericity: An Introduction. In The Generic Book, ed. by Gregory Carlson and Francis Jeffry Pelletier, 1-124. Chicago: University of Chicago Press.

Malamud, Sophia A. 2006. Semantics and pragmatics of arbitrariness. Doctoral Dissertation, University of Pennsylvania.

Malamud, Sophia A. 2012. Impersonal indexicals: one, you, man, and du. Journal of Comparative Germanic Linguistics 15:1-48.

https://doi.org/10.1007/s10828-012-9047-6.

Malamud, Sophia A. 2013. (In)definiteness-driven typology of arbitrary items. Lingua 126:1-31. https://doi.org/10.1016/j.lingua.2012.11.003.

Mari, Alda, Claire Beyssade, and Fabio del Prete. 2013. Introduction. In Genericity, ed. by Alda Mari, Claire Beyssade, and Fabio del Prete, 1-92. Oxford: Oxford University Press. 
Safir, Ken. 2004. The syntax of anaphora. Oxford: Oxford University Press.

Siewierska, Anna. 2004. Person. Cambridge: Cambridge University Press.

Stump, Gregory T. 1985. The Semantic Variability of Absolute Constructions. Dordrecht: Reidel.

Sudo, Yasutada. 2012. On the Semantics of Phi Features on Pronouns. Doctoral Dissertation, MIT.

de Swart, Henriette, Yoad Winter, and Joost Zwarts. 2007. Bare nominals and reference to capacities. Natural Language and Linguistic Theory 25:195-222.

https://doi.org/10.1007/s11049-006-9007-4.

Szabo, Zoltan Gendler. 2003. On qualification. Philosophical Perspectives 17 (Language and Philosophical Linguistics):409-438.

https://doi.org/10.1111/j.1520-8583.2003.00016.x.

Zifonun, Gisela. 1998. Zur Grammatik von Subsumtion und Identität. Herr Schulze als erfahrener Lehrer.... Deutsche Sprache 1/98:1-17.

Zobel, Sarah. 2010. Non-Standard Uses of German 1st Person Singular Pronouns. In JSAI-isAI, LNAI 6284, ed. by Kumiyo Nakakoji, Yohei Murakami, and Eric McCready, 292-311. Springer.

Zobel, Sarah. 2014. Impersonally Interpreted Personal Pronouns. Doctoral Dissertation, Universität Göttingen, Staats- und Universitätsbibliothek Göttingen. http://hdl. handle. net/11858/00-1735-0000-0023-991B-2. 
Zobel, Sarah. 2016. A pragmatic analysis of German impersonally used first person singular ich. Pragmatics 26:379-416.

https://doi.org/10.1075/prag.26.3.03zob.

Zobel, Sarah. 2017. The sensitivity of natural language to the distinction between class nouns and role nouns. In Proceedings of SALT 27, ed. by Dan Burgdorf, Jacob Collard, Sireemas Maspong, and Brynhildur Stefánsdóttir, 438-458.

https://doi.org/10.3765/salt.v27i0.4182.

Zobel, Sarah. 2018. An analysis of the semantic variability of weak adjuncts and its problems. In Proceedings of Sinn und Bedeutung 22, vol. 2, ZASPiL 61, ed. by Uli Sauerland and Stephanie Solt, 499-516. Berlin: ZAS. https://doi.org/10.21248/zaspil.61.2018.509.

Zobel, Sarah. 2019. Accounting for the causal link between free adjuncts and their host clauses. In Proceedings of Sinn und Bedeutung 23, Vol. 2, ed. by M.T̃eresa Espinal, Elena Castroviejo, Manuel Leonetti, Louise McNally, and Cristina Real-Puigdollers, 489-506. Bellaterra: Universitat Autònoma de Barcelona.

https://doi.org/10.18148/sub/2019.v23i2.626.

Institutt for lingvistiske og nordiske studier

Universitetet i Oslo

Niels Henrik Abels vei 36, 0313 Oslo, Norway

sarah.zobel@iln.uio.no 


\section{Endnotes}

I thank Yvonne van Baal, Karin Beijering, Pritty Patel-Grosz, Frank Sode, Jozina Vander Klok, Thomas Weskott, and two anonymous reviewers for helpful comments and discussion. This research received funding from the European Union's Horizon 2020 program under the Marie Skłodowska-Curie grant agreement No 842363.

${ }^{1}$ The discourse particle doch often cooccurs with impersonally used ich but is not necessary for the impersonal interpretation to be available (see Zobel 2014:50). Since discourse particles are well-known to make no contribution to the asserted content of a clause (e.g., Grosz 2021), doch cannot be the source of the generic interpretation of (3).

${ }^{2}$ Generic sentences are well-known to allow for exceptions (e.g., Krifka et al. 1995; Mari et al. 2013). Hence, if the addressee $\mathrm{A}$ of (1b) is one of the exceptions to this rule, then "A can't expect A's guests to pay for A's party" will be false. That is why it is felicitous to continue (1b) with "Well, YOU can, but people in general can't" (where capitals encode focus; see, e.g., Kitagawa and Lehrer 1990).

${ }^{3}$ In this section, I will introduce and use A\&N's (2018) own terminology (e.g., "generic flavor"). As I point out below, however, for most of these terms it remains unclear which concepts or notions they are meant to describe.

${ }^{4}$ I report A\&N's translations and acceptability judgments as they are. My Dutch consultants do not agree with all of these judgments. Since my goal is not to discuss Dutch, I will not address these discrepancies and only point out relevant differences in footnotes.

${ }^{5}$ It is not clear to me whether (4) is fully acceptable or not. A\&N say that examples of 
this kind are attested, but that they find them "somewhat marked" (p. 109). My two Dutch consultants judge (4) to be semantically odd, and only marginally acceptable.

${ }^{6} \mathrm{My}$ Dutch consultants accept both sentences in (9). So, I was not able to confirm the contrast for $j i j$ that motivates A\&N's introduction of imaginary guises.

${ }^{7}$ As an anonymous reviewer points out, A\&N's notion of guise might be comparable to notions that are discussed in the literature under a different name. For instance, A\&N's guises might be comparable to Fine's (1982) qua-objects. Since A\&N do not define their notion of guise, any further comparison would be pure speculation, though.

${ }^{8}$ The judgments reported in this and the next section reflect the judgments of 4-5 native speakers of German, as well as my own native speaker intuitions.

${ }^{9} \mathrm{URL}:<$ https://www.donaukurier.de/sport/lokalsport/hilpoltstein/Herrnsberg-taumelt-indie-Kreisliga-Relegation;art1725,2425753> (last access: July 23, 2021)

${ }^{10}$ I thank an anonymous reviewer for suggesting this line of argumentation.

${ }^{11}$ URL: <https://www.a4-freunde.com/forum/showthread.php?42231-8E-B6-Chip-zurVerbrauchsreduzierung > (last access: July 9, 2021)

${ }^{12}$ The analysis of (20) is close to A\&N's description of the Dutch counterpart of (3) in (4), which would be expected if Dutch $i k$ does not have an impersonal use.

${ }^{13} \mathrm{URL}:<$ https://dogpackr.ch/warum-ist-mein-hund-plotzlich-so-uberdreht/> (last access: July 1, 2021) 